\title{
Public Health Risks Associated with Low Concentration of Food-Borne Toxins
}

\section{Amir Mohammad Malvandi*}

Department of Biomedical and Clinical Sciences, University of Milan, Italy

Despite the health safety monitoring and strict regulations, in the contemporary life of every individual depending on the lifestyle one person can consume some amounts of toxins with his daily meals which are mostly solved in the foods. Standardization and health safety monitoring of food production and selling chains are evolving continually; however, there are always tolerable levels of toxins even if it is very low. Among all the toxic materials allergens, pathogenic microorganisms, mycotoxins, and heavy metals are the most notified hazardous materials in the food-borne toxins. Allergens could be defined by the experience and avoided or tolerated with anti-inflammatory treatments. The pathogenic microorganisms often changed food products shape or smell in a visible sense and educated consumers can avoid using them. But the heavy metals such as arsenic or mycotoxins are taste- and color-less food contaminants that cannot be recognized without analytical devices. That is the toxicity of these materials is much more important than the others. Many countries have adopted regulatory approaches to limit mycotoxin and metal element exposure. But these regulations are also under influence of world trade. For instance, in 2012 and 2015 mycotoxin contaminations were the main border rejection in the European Union. Among the mycotoxins, Aflatoxins were the primary toxins associated with notifications and nuts, processed food containing nuts, fruits and vegetables, seeds, herbs and spices, and foodstuffs, were the most affected categories [1]. Based on an estimation of the Food and Agriculture Organization of the United Nations (FAO) and approximate of $25 \%$ of the total world production of cereals has mycotoxin contamination [2] other foods like fruits, spices, nuts and their by-products could be another important target of mycotoxins. In the food production and agricultural practice, there are several points that the fungal contamination could occur that can categorize in the two main stages: (1) Pre-selling steps, (2) Post-selling. In the pre-selling category, the points are pre-harvest, harvest and drying or processing, storage and food processing and/or packaging and transport. On the post-selling category, supermarkets storage, home and final consumer storage and usages are the possible points of contamination. Although the probability of Mycotoxins contaminations is much higher before food processing, the incidence of fungal contamination after this step should be also taken into the consideration. It is since even if on the very low water content food products after opening the package the water adsorption will provide an optimal environment for fungal growth and consequent mycotoxin contamination [3]. Among all the mycotoxins the Aflatoxins (AF) are the most frequent and potent toxic molecules as a common contaminant of our food [4,5]. Apart from the well-known carcinogenic activity of this toxin recently the immunotoxicology effects of them revealed more relevancy to the public health topic. A mix of AFs molecule at a very low concentration that is considered as environmentally relevant level could trigger innate inflammatory reactions in the human leucocytes [6]. At the same low concentration AFB1 could make inflammatory condition in Central Nerves System (CNS)-derived astrocytes and microglial cells [7]. The low dose of AFs, as well as the other toxins, is more probable to occur and at this concentration AF not considered to make significant carcinogenesis, but the oxidative metabolism of AFs is believed to make the inflammatory reaction. At is mentioned, the inflammation could trigger in leucocytes and CNS cells as well. The modulation in the homeostatic situation of immune cells in blood and lymph system or key cells such as astrocytes or microglial cells in CNS should be considered as a public health alert. These deregulations could easily make exposed individuals to a significantly higher susceptibility to autoimmune and neurodegenerative disease. The epidemiological studies are needed to address this issue. As well, more investigation is required to make a clear molecular mechanism of action in a lowdose exposure of AFs at cells. Altogether, the effects of toxins in low concentration should be much more in focus of research and public health education programs as they can escape from routine detections or could occur based on poor lifestyle.

\section{References}

1. Rasff (2015) The Rapid Alert System for Food and Feed - 2015 annual report European Commission-Health and Food Safety.

2. Rice LG, Ross PF (1994) Methods for Detection and Quantitation of Fumonisins in Corn, Cereal Products and Animal Excreta. Journal of Food Protection 57: 536-540.

3. Gibson AM, Baranyi J, Pitt JI, Eyles MJ, Roberts TA (1994) Predicting funga growth: the effect of water activity on Aspergillus flavus and related species. Int J Food Microbiol 23: 419-431.

4. Dai Y, Huang K, Zhang B, Zhu L, Xu W (2017) Aflatoxin B1-induced epigenetic alterations: An overview. Food Chem Toxicol 109: 683-689.

5. Es'haghi Z, Beheshti HR, Feizy J (2014) Extraction of aflatoxins from food samples using graphene-based magnetic nanosorbents followed by highperformance liquid chromatography: a simple solution to overcome the problems of immunoaffinity columns. J Sep Sci 37: 2566-2573.

6. Malvandi AM, Mehrzad J, Saleh-moghaddam M (2013) Biologically relevan doses of mixed aflatoxins B and G up-regulate MyD88, TLR2, TLR4 and CD14 transcripts in human PBMCs. Immunopharmacol Immunotoxicol 35: 528-532.

7. Mehrzad J, Malvandi AM, Alipour M, Hosseinkhani S (2017) Environmentally relevant level of aflatoxin B1 elicits toxic pro-inflammatory response in murine CNS-derived cells. Toxicol Lett 279: 96-106.

*Corresponding author: Malvandi AM, Department of Biomedical and Clinical Sciences, University of Milan, Milan, Italy, Tel: +39-02-50319833; E-mail: amir.malvandi@unimi.it

Received September 26, 2017; Accepted November 16, 2017; Published November 25, 2017

Citation: Malvandi AM (2017) Public Health Risks Associated with Low Concentration of Food-Borne Toxins. J Blood Lymph 7: 187. doi: 10.4172/21657831.1000187

Copyright: (C) 2017 Malvandi AM. This is an open-access article distributed unde the terms of the Creative Commons Attribution License, which permits unrestricted use, distribution, and reproduction in any medium, provided the original author and source are credited. 